\title{
Pengaruh Penerapan Model Pembelajaran Kooperatif Tipe Jigsaw Terhadap Kemampuan Komunikasi Matematis Ditinjau Dari Kemandirian Belajar Siswa Sekolah Menengah Pertama Pekanbaru
}

\author{
Suci Ratna Sari, Depi Fitraini \\ Pendidikan Matematika, Fakultas Tarbiyah dan Keguruan \\ Universitas Islam Negeri Sultan Syarif Kasim Riau \\ E-mail: suciratnasari179@gmail.com
}

\begin{abstract}
ABSTRAK. Penelitian ini bertujuan untuk menyelidiki ada tidaknya perbedaan kemampuaan komunikasi matematis antara siswa yang mengikuti pembelajaran kooperatif tipe Jigsaw dengan siswa yang tidak mengikuti pembelajaran kooperatif tipe Jigsaw di Sekolah Menengah Pertama Negeri 40 Pekanbaru. Penelitian ini merupakan penelitian Quasi Eksperimen yaitu The Nonequivalent Posttest-Only Control Group Design. Populasi dalam penelitian ini adalah seluruh siswa kelas VII Sekolah Menengah Pertama Negeri 40 Pekanbaru. Sampel penelitian ini dipilih dengan menggunakan teknik Purposive Sampling, terpilih kelas VII.E sebagai kelas eksperimen yang diberikan model pembelajaran kooperatif tipe Jigsaw dan kelas VII.B sebagai kelas kontrol yang diberikan model pembelajaran yang diterapkan oleh guru. Teknik analisis data yang digunakan peneliti yaitu uji-t dan anova dua jalan (two way anova). Instrumen yang digunakan adalah tes uraian untuk mengukur kemampuan komunikasi matematis siswa dan angket untuk mengukur tingkat kemandirian belajar siswa. Berdasarkan hasil penelitian disimpulkan bahwa (1) terdapat perbedaan kemampuaan komunikasi matematis antara siswa yang mengikuti pembelajaran kooperatif tipe Jigsaw dengan siswa yang tidak mengikuti pembelajaran kooperatif tipe Jigsaw. (2) tidak terdapat interaksi antara pembelajaran menggunakan model pembelajaran ditinjau dari kemandirian belajar terhadap kemampuan komunikasi matematis siswa. Dengan demikian, secara umum model pembelajaran kooperatif tipe Jigsaw berpengaruh terhadap kemampuan komunikasi matematis yang ditinjau dari kemandirian belajar siswa Sekolah Menengah Pertama Negeri 40 Pekanbaru.
\end{abstract}

Kata kunci: Kooperatif Tipe Jigsaw, Kemampuan Komunikasi Matematis, Kemandirian Belajar

\section{PENDAHULUAN}

Matematika merupakan salah satu pengetahuan dasar yang menjadi pendukung bagi kemajuan teknologi, yang perlu diajarkan sejak dari sekolah dasar sampai keperguruan tinggi. Matematika adalah ratunya ilmu dan sekaligus berfungsi untuk melayani ilmu pengetahuan karena matematika merupakan kunci dari ilmu pengetahuan dan teknologi baik aspek terapannya maupun aspek penalarannya. Matematika berfungsi untuk melayani ilmu pengetahuan artinya selain tumbuh dan berkembang untuk dirinya sendiri sebagai suatu ilmu, matematika juga melayani kebutuhan ilmu pengetahuan dalam pengembangan dan operasionalnya (Rachmayani, 2014, p. 14).

Menurut Permendikbud Nomor 21 Tahun 2016 tentang Standar Isi Pendidikan Dasar dan Menengah menetapkan bahwa kompetensi yang harus dicapai pada pelajaran matematika adalah sebagai berikut: (1) menunjukkan sikap logis, kritis, analitis, kreatif, cermat dan teliti, bertanggung jawab, responsif, dan tidak mudah menyerah dalam memecahkan masalah, (2)memiliki rasa ingin tahu, semangat belajar yang kontinu, rasa percaya diri, dan ketertarikan pada matematika, (3) memiliki rasa percaya pada daya dan kegunaan matematika, yang terbentuk melalui pengalaman belajar, (4) memiliki sikap terbuka, objektif dalam interaksi kelompok maupun aktivitas seharihari, (5) memiliki kemampuan mengkomunikasikan gagasan matematika dengan jelas. 
Berdasarkan poin kelima, jelas bahwa salah satu kemampuan yang harus dimiliki siswa adalah kemampuan komunikasi matematis.

Untuk menambah informasi yang dibutuhkan, peneliti melakukan studi pendahuluan berupa pemberian tes soal kemampuan komunikasi matematis siswa, kegiatan observasi langsung dan wawancara dengan guru bidang studi matematika di salah satu sekolah yang ada di Pekanbaru, yakni di SMP Negeri 40 Pekanbaru yang beralamat di Jalan Garuda Sakti KM. 3 (Ketitiran). Adapun informasi yang diperoleh dari memberikan tes soal kemampuan komunikasi matematis siswa yaitu untuk memperkuat hasil dari kegiatan observasi langsung dan wawancara. Hasil yang diperoleh bahwa sebagian siswa memiliki kemampuan komunikasi yang masih rendah dalam pelajaran matematika. Hal ini terlihat dari beberapa hal yaitu: (1) $65 \%$ siswa belum bisa mengidentifikasikan apa yang diketahui, ditanyakan dan kelengkapan unsur-unsur yang terdapat dalam soal, (2) 70\% siswa yang tidak dapat dengan baik menyatakan ide matematika ke dalam model matematika, (3) 75\% siswa yang tidak dapat menghubungkan benda-benda nyata, gambar, diagram kedalam ide matematika (4) $75 \%$ siswa tidak dapat memberikan dan menjelaskan jawaban dengan menggunakan bahasa sendiri terbukti dari hasil tes kemampuan komunikasi yang diberikan.

Kondisi di atas menggambarkan bahwa kemampuan komunikasi matematis siswa dalam pembelajaran matematika harus terus ditingkatkan, mengingat kemampuan komunikasi matematis dapat mempermudah siswa memahami materi-materi dan pemecahan masalah yang diberikan guru. Walaupun ditemukan gejala-gejala seperti yang telah diuraikan, guru bidang studi telah berupaya untuk mengatasi masalah-masalah tersebut dengan menerapkan metode ceramah, tanya jawab, pemberian tugas-tugas, diskusi atau pengulangan materi. Namun usaha tersebut belum cukup untuk mengatasi masalah-masalah yang dialami siswa. Maka perlu adanya perbaikan. Perbaikan tersebut adalah dengan menerapkan model, strategi maupun metode pembelajaran yang tepat agar dapat meningkatkan kemampuan komunikasi matematis siswa. Salah satu model yang digunakan peneliti untuk meningkatkan kemampuan komunikasi matematis siswa adalah model pembelajaran kooperatif tipe Jigsaw.

Model pembelajaran kooperatif tipe Jigsaw merupakan salah satu model yang mendukung siswa dalam meningkatkan kemampuan komunikasi matematis dengan baik. Model pembelajaran kooperatif tipe Jigsaw ini siswa memiliki banyak kesempatan untuk mengemukakan pendapat dan mengolah informasi yang didapat dan dapat meningkatkan keterampilan berkomunikasi, anggota kelompok bertanggung jawab terhadap keberhasilan kelompoknya dan ketuntasan bagian materi yang dipelajari dan dapat menyampaikan informasinya kepada kelompok lain (Rusman, 2016, p. 218). Pembelajaran kooperatif Jigsaw ialah kegiatan belajar secara kelompok kecil, siswa belajar dan bekerja sama sampai kepada pengalaman belajar yang maksimal, baik pengalaman individu maupun pengalaman kelompok. Manfaat menerapkan pembelajaran kooperatif tipe Jigsaw adalah siswa belajar menemukan konsep yang dipelajari dengan mengaplikasikan pengetahuan yang dimilikinya dalam menyelesaikan masalah (Asri, 2014, p. 87).

Faktor lain yang juga menentukan keberhasilan siswa dalam menerima pelajaran adalah kemampuan kemandirian belajar. Kemandirian belajar atau Self-Regulated Learning diperlukan agar siswa mempunyai tanggung jawab dalam mengatur dan mendisiplinkan dirinya, selain itu dalam mengembangkan kemampuan belajar atas kemauan sendiri (Mashuri, 2012, p. 24). Kemandirian dalam belajar dalam memperoleh informasi tidak hanya bergantung pada guru dalam proses pembelajaran atau tatap muka di kelas saja, melainkan pada pemanfaatan dengan menggunakan perpustakaan atau membentuk kelompok belajar.

Kemandirian belajar siswa juga diperlukan dalam pembelajaran kooperatif tipe Jigsaw, karena dalam kooperatif tipe Jigsaw setiap anggota dari kelompok membagi tugas kepada masing-masing anggotanya untuk menjadi ahli dalam satu submateri pelajaran, kemudian masing-masing ahli submateri yang sama akan membentuk kelompok baru untuk mendiskusikan submateri yang sama. Kemudian setelah itu kembali kekelompok semula disini siswa bertanggung jawab untuk menjelaskan submateri sesuai keahliannya masing-masing keanggota kelompok. Kemudian mereka di uji dengan pemberian kuis yang dikerjakan individu. Nilai yang diperoleh masing-masing anggota kelompok dijumlahkan untuk memperoleh nilai kelompok. Berdasarkan uraian tersebut kemandirian belajar mempunyai keterkaitan dengan pembelajaran Kooperatif tipe Jigsaw. 


\section{METODE}

Penelitian ini merupakan penelitian Quasi Eksperimen yaitu The Nonequivalent Posttest-Only Control Group Design. Populasi dalam penelitian ini adalah seluruh siswa kelas VII Sekolah Menengah Pertama Negeri 40 Pekanbaru. Sampel penelitian ini dipilih dengan menggunakan teknik Purposive Sampling, terpilih kelas VII.E sebagai kelas eksperimen yang diberikan model pembelajaran kooperatif tipe Jigsaw dan kelas VII.B sebagai kelas kontrol yang diberikan model pembelajaran yang diterapkan oleh guru. Teknik analisis data yang digunakan peneliti yaitu uji-t dan anova dua jalan (two way anova).

\section{HASIL}

Data yang diperoleh yaitu kemandirian belajar siswa, kemampuan komunikasi matematis dengan menerapkan model pembelajaran kooperatif tipe Jigsaw pada kelas eksperimen dan dibandingkannya dengan hasil yang diperoleh oleh kelas kontrol. Berikut akan dijelaskan secara singkat mengenai uji normalitas, uji homogenitas, uji t dan anova dua jalan (two way anova).

\section{Kemandirian Belajar Siswa}

Uji homogenitas yang peneliti lakukan terhadap hasil angket kemandirian belajar siswa dengan uji F. Uji homogenitas melakukan uji varians terbesar dibanding varians terkecil. Setelah dilakukan analisis menggunakan uji $\mathrm{F}$, diperoleh nilai $F_{\text {hitung }}$ yaitu 1,20 , sedangkan untuk nilai $F_{\text {tabel }}$ yaitu 1,98. Maka $F_{\text {hitung }}<F_{\text {tabel }}$. Dapat disimpulkan bahwa tersebut adalah homogen.

Selanjutnya dilakukan uji normalitas dengan chi-kuadrat hasil analisis data angket kemandirian belajar diperoleh nilai $\chi_{\text {hitung }}^{2}$ kelas eksperimen sebesar 6,51, sedangkan untuk nilai $\chi_{\text {tabel }}^{2}$ dalam taraf signifikan 5\% yaitu 11,07. Maka $\chi^{2}$ bitung $\leq \chi^{2}$ tabel sehingga dapat disimpulkan bahwa data kelas eksperimen berdistribisi normal. Selanjutnya untuk kelas kontrol diperoleh nilai $\chi_{\text {hitung }}^{2}$ sebesar 2,12, sedangkan untuk nilai $\chi_{\text {tabel }}^{2}$ dalam taraf signifikan 5\% yaitu 11,07. Karena $\chi^{2}$ bitung $\leq \chi_{\text {tabel }}^{2}$ maka dapat disimpulkan data kelas kontrol berdistribusi normal.

\section{Kemampuan Komunikasi Matematis (Postest)}

Pengujian homogenitas yang peneliti lakukan adalah dari hasil tes kemampuan komunikasi

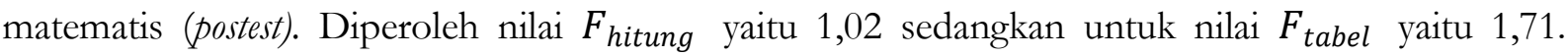
Dengan demikian, diketahui bahwa $F_{\text {hitung }}<F_{\text {tabel }}$ yaitu $1,02<1,71$ sehingga dapat disimpulkan bahwa varians tersebut adalah homogen.

Selanjutnya dilakukan uji normalitas dengan chi-kuadrat diperoleh nilai $\chi_{\text {hitung }}^{2}$ kelas eksperimen sebesar 7,17, sedangkan untuk nilai $\chi_{\text {tabel }}^{2}$ dalam taraf signifikan 5\% yaitu 11,07. Maka $\chi^{2}$ bitung $\leq \chi^{2}$ tabel sehingga dapat disimpulkan bahwa data kelas eksperimen berdistribisi normal. Selanjutnya untuk kelas kontrol diperoleh nilai $\chi_{\text {hitung }}^{2}$ sebesar 2,27, sedangkan untuk nilai $\chi_{\text {tabel }}^{2}$ dalam taraf signifikan $5 \%$ yaitu 11,07 . Karena $\chi^{2}$ bitung $\leq \chi^{2}$ tabel maka dapat disimpulkan data kelas kontrol berdistribusi normal.

Setelah dilakukan uji normalitas dan uji homogenitas pada sampel maka selanjutnya melakukan uji t. Hal ini dapat dilihat dari $t_{\text {hitung }}$ yaitu 1,76 sedangkan untuk nilai $t_{\text {tabel }}$ yaitu 1,67 berarti besar $t_{\text {hitung }}$ dibandingkan $t_{\text {tabel }}$ pada taraf signifikan $5 \%$ adalah 1,76 $>1,67$ atau $t_{\text {hitung }} \geq$ $t_{\text {tabel }}$, maka $H_{a}$ diterima dan $H_{o}$ ditolak. Dengan demikian dapat disimpulkan terdapat perbedaan kemampuan komunikasi matematis siswa antara kelas yang diterapkan model pembelajaran kooperatif tipe Jigsaw dengan kelas yang tidak diterapkan model pembelajaran kooperatif tipe Jigsaw.

\section{Uji Anova Dua Jalan (Two Way Anova)}


Interaksi antara model pembelajaran ditinjau dari kemandirian belajar terhadap kemampuan komunikasi matematis siswa terdapat hasil perhitungan $F_{\text {hitung }}$ dibandingkan dengan $F_{\text {tabel }}$. Nilai $F_{\text {hitung }}=-0,59$ sedangkan nilai $F_{\text {tabel }}$ dengan derajat kebebasan $(\mathrm{dk})=2$, pada taraf signifikan $5 \%$ adalah 3,13 hal ini berarti bahwa $F_{\text {hitung }}<F_{\text {tabel }}$ dimana $-0,59<3,13$. Maka dapat ditarik kesimpulan bahwa $H_{0}$ diterima dan $H_{a}$ ditolak. Artinya tidak terdapat interaksi antara model pembelajaran ditinjau dari kemandirian belajar terhadap kemampuan komunikasi matematis siswa.

\section{PEMBAHASAN}

Penggunaan model pembelajaran kooperatif tipe Jigsaw membuat siswa lebih mengerti dengan apa yang telah ditemukannya sendiri. Proses pembelajaran yang dilakukan selama enam kali pertemuan telah berjalan dengan baik. Sebelum menerapkan model pembelajaran kooperatif tipe Jigsaw siswa dikelompokkan berdasarkan kritera kemandirian belajar yaitu tinggi, sedang dan rendah. Pada kelas eksperimen didapat bahwa kemandirian belajar tinggi sebanyak 6 siswa, kemandirian belajar sedang sebanyak 26 siswa, dan kemandirian belajar rendah sebanyak 7 siswa. Sedangkan pada kelas kontrol didapat bahwa kemandirian belajar tinggi 5 siswa, kemandirian belajar sedang 25 siswa dan kemandirian belajar rendah 9 siswa.

Pada pertemuan pertama siswa masih banyak yang bingung dengan tahapan belajar yang diterapkan, sehingga setiap tahapannya tidak terlaksana dengan baik. Kegiatan dengan menggunakan kelompok yang disusun secara heterogen membutuhkan waktu untuk siswa agar menyesuaikan diri dengan kelompoknya. Saat kegiatan diskusi, pada pertemuan pertama dan kedua kegiatan kurang kondusif karena siswa masih belum terbiasa dengan sistem pembelajaran yang digunakan dan siswa cenderung mengerjakan lembar kegiatannya sendiri tanpa mau berdiskusi dengan temannya. Pada saat mempresentasikan jawaban mereka di depan kelompok lain, awalnya siswa masih malu-malu dan kurang percaya diri.

Pada tahapan ketiga sudah mulai berangsung membaik walaupun masih ada siswa yang belum terlibat secara aktif dan pada saat mempresentasikan jawaban mereka di depan kelompok lain siswa sudah tidak malu-malu dan mulai percaya diri. Pada saat pertemuan keempat, kelima dan keenam kegiatan diskusi sudah berjalan baik bahkan siswa sudah tahu apa yang harus dikerjakan dan siswa berantusias dan berlomba-lomba dalam memperoleh nilai kelompok yang tinggi. Kemampuan komunikasi matematis siswa juga terus membaik dan semakin lancar dalam menyelesaikan lembar kegiatan, berani mengajukan pertanyaan dan mengungkapkan pendapat kepada teman sekelompok dan teman lainnya.

Berdasarkan rata-rata yang diperoleh dari hasil analisis data tentang kemampuan komunikasi matematis siswa pada pokok bahasan segiempat di SMP Negeri 40 Pekanbaru terlihat bahwa rata- rata kemampuan komunikasi matematis siswa kelas eksperimen yang menggunakan model pembelajaran kooperatif tipe Jigsaw lebih tinggi dari pada rata-rata kemampuan komunikasi matematis kelas kontrol yang tidak menggunakan model pembelajaran kooperatif tipe Jigsaw.

Pada hipotesis pertama, untuk mengetahui perbedaan kemampuan komunikasi matematis antara siswa yang mengikuti pembelajaran kooperatif tipe Jigsaw dengan siswa yang tidak mengikuti pembelajaran kooperatif tipe Jigsaw, untuk itu dilakukan uji t. Sebelum melakukan uji t data harus normal dan homogen. Sehingga dilakukan uji Chi-Kuadrat untuk normalitas dan uji F untuk homogenitas. Setelah diuji, didapat bahwa data tersebut normal dan homogen sehingga dapat dilanjutkan dengan uji t. Berdasarkan hasil analisis uji t diperoleh $t_{\text {hitung }}=1,76$. Dengan $d k=$ 76 dan taraf signifikan $5 \%$, maka diperoleh $t_{\text {tabel }}=1,67$. Berdasarkan perhitungan, diketahui bahwa $t_{\text {hitung }} \geq t_{\text {tabel }}$ yaitu $1,76 \geq 1,67$, sehingga $H_{a}$ diterima dan $H_{o}$ ditolak. Artinya terdapat perbedaan yang signifikan antara siswa yang mengikuti pembelajaran kooperatif tipe Jigsaw dengan siswa yang tidak mengikuti pembelajaran kooperatif tipe Jigsaw. 
Hasil penerapan model pembelajaran kooperatif tipe Jigsaw pada kelas eksperimen menunjukkan bahwa siswa menjadi lebih aktif belajar bersama teman-temannya. Siswa juga diberikan kuis komunikasi matematis untuk melihat dan mengevaluasi hasil belajar siswa setiap pertemuan dalam meningkatkan komunikasi matematis.

Pada hipotesis kedua, berdasarkan perhitungan uji anova dua jalan diperoleh $F_{\text {hitung }}<$ $F_{\text {tabel }}$ dimana $-0,59<3,13$, maka $H_{o}$ diterima dan $H_{a}$ ditolak. Sehingga menunjukkan bahwa tidak terdapat interaksi antara model pembelajaran ditinjau dari kemandirian belajar terhadap kemampuan komunikasi matematis siswa. Dengan kata lain model pembelajaran terhadap kemampuan komunikasi matematis tidak bergantung pada kemandirian belajar, dan kemandirian belajar terhadap kemampuan komunikasi matematis tidak bergantung pada model pembelajaran yang digunakan.

Beberapa hal yang perlu diperhatikan terkait pelaksaan pembelajaran kooperatif tipe Jigsaw yaitu dalam pelaksanaan model pembelajaran kooperatif tipe Jigsaw sebaiknya memperhatikan dan memanfaatkan waktu dengan sebaik-baiknya karena dalam model ini adanya pertukaran kelompok, agar langkah-langkah dalam model pembelajaran kooperatif tipe Jigsaw sesuai dengan waktu yang sudah ditetapkan demi tercapainya tujuan yang diharapkan. Penerapan model pembelajaran kooperatif tipe Jigsaw sebaiknya didukung menggunakan bantuan media atau alat peraga matematika sehingga memunculkan banyak ide-ide kreatif dari siswa, agar lebih memaksimalkan kegiatan diskusi. Kemudian kemampuan guru dalam mengkondisikan kelas menjadi faktor utama keberhasilan guru dalam proses belajar mengajar, sehingga peneliti menyarankan jika guru ingin menggunakan model pembelajaran kooperatif tipe Jigsaw yang harus guru lakukan adalah mengkondisikan siswa lebih dulu.

\section{KESIMPULAN}

Berdasarkan hasil penelitian yang peneliti laksanakan di SMP Negeri 40 Pekanbaru pada kelas VII semester genap tahun pelajaran 2017/2018, diperoleh beberapa kesimpulan yang merupakan jawaban atas pertanyaan-pertanyaan yang diajukan dalam rumusan masalah. Selain itu, dalam kesimpulan ini diungkapkan pula beberapa hasil yang ditemukan dalam penelitian yaitu 1) Terdapat perbedaan kemampuan komunikasi matematis antara siswa yang mengikuti pembelajaran kooperatif tipe jigsaw dengan siswa yang tidak mengikuti pembelajaran kooperatif tipe Jigsaw. 2) Tidak terdapat interaksi antara model pembelajaran yang ditinjau dari kemandirian belajar terhadap kemampuan komunikasi matematis siswa.

\section{PENGHARGAAN}

Terima kasih kepada FTK UIN Suska Riau dan SMP Negeri 40 Pekanbaru dan pihak lainnya yang telah membantu terlaksananya penelitian ini.

\section{DAFTAR PUSTAKA}

Asri, Khairul. 2014. Meningkatkan Kemampuan Pemecahan Masalah dan Komunikasi Matematis Melalui Penerapan Pembelajaran Kooperatif Tipe Jigsaw Pada Siswa Sekolah Menengah Atas. Jurnal Didaktik Matematika Universitas Syiah Kuala, Banda Aceh, Vol. 1, No. 2.

Fachrurazi. 2011. Penerapan Pembelajaran Berbasis Masalah untuk Meningkatkan Kemampuan Berpikir Kritis dan Komunikasi Matematis Siswa Sekolah Dasar dalam Jurnal Edisi Khusus No.1, Agustus. 
Ikin Asep Sugandi, 2013. Pengaruh Pembelajaran Berbasis Masalah dengan Setting Kooperatif Jigsaw terhadap Kemandirian Belajar Siswa SMA dalam Jumal Ilmiah Program Studi Matematika STKIP Siliwangi Bandung, Vol 2, No.2.

Mashuri, Imam. 2012. Pengaruh Pembelajaran Berbasis Masalah dan Inkuiri ditinjau dari Kemandirian Belajar Siswa Kelas X SMA Negeri Kabupaten Blora. JMEE Volume II Nomor 1.

Menteri Pendidikan dan Kebudayaan Republik Indonesia.2016. Peraturan Menteri Pendidikan dan Kebudayaan Republik. Indonesia Nomor 21 Tabun 2016 tentang Standar Isi Pendidikan Dasar dan Menengah. Jakarta.

Rachmayani, Dwi. 2014. Penerapan Pembelajaran Reciprocal Teaching Untuk Meningkatkan Kemampuan Komunikasi Matematis dan Kemandirian Belajar Matematika Siswa. Jurnal Pendidikan Unsika.Volume 2 Nomor 1.

Ramdani, Yani. 2012. Pengembangan Instrumen dan Bahan Ajar Untuk Meningkatkan Kemampuan Komunikasi, Penalaran dan Koneksi Matematis dalam Konsep Integral”, dalam Jurnal Penelitian Pendidikan FMIPA UNISBA. Vol. 13 No.1.

Suhendri dan Mardalena. Pengaruh Metode Pembelajaran Problem Solving terhadap Hasil Belajar Matematika ditinjau dari Kemandirian Belajar. Jurnal Formatif 3(2) Program Studi Pendidikan Matematika, Fakultas Teknik, Matematika dan IPA. Universitas Indraprasta PGRI.

Suhendri Huri. Pengaruh Kecerdasan Matematis-Logis dan Kemandirian Belajar terhadap Hasil Belajar Matematika, dalam Jurnal Program Studi Pendidikan Matematika Universitas Indraprasta PGRI (UNINDRA).

Syahri Andi Alim. 2017. Pengaruh Penerapan Pendekatan Realistik Setting Kooperatif Terhadap Kemampuan Komunikasi Matematika Siswa Kelas VIII dalam (MaPan: Jurnal Matematika dan Pembelajaran, Vol. 5, No. 2.

Syaripah. 2014. Penerapan Pembelajaran Kooperatif Tipe Jigsaw dalam Upaya Meningkatkan Kemampuan Pemecahan Masalah dan Kemampuan Komunikasi Matematis Siswa, dalam Jurnal Program Pascasarjana UNIMED Mrdan, forum Paedagogik Vol. VI, No.01.

Tahar Irzan dan Enceng. 2006. Hubungan Kemandirian Belajar dan Hasil Belajar pada Pendidikan Jarak Jauh “, dalam Jurnal Pendidikan Terbuka dan Jarak Jauh, Volume. 7, Nomor 2, September.

Zuliana Eka. Meningkatkan Kemampuan Komunikasi Matematika Peserta Didik Kelas VIII B Mts N Kudus Melalui Model Cooperative Learning Tipe Jigsaw Berbantuan Kartu Masalah Materi Kubus Dan Balok, Dosen 11 PGSD UMK. 